\title{
Principal Drivers and Conservation Solutions to the Impending Primate Extinction Crisis: Introduction to the Special Issue
}

\author{
Alejandro Estrada ${ }^{1,2}$. Paul A. Garber ${ }^{2,3}$
}

Received: 24 November 2021 / Accepted: 24 January 2022 / Published online: 15 February 2022

(c) The Author(s), under exclusive licence to Springer Science+Business Media, LLC, part of Springer Nature 2022

\begin{abstract}
Nonhuman primates are facing an impending extinction crisis with over $65 \%$ of species listed as Vulnerable, Endangered, or Critically Endangered, and 93\% characterized by declining populations. Primary drivers of primate population decline include deforestation, principally for industrial agriculture and the production of food and nonfood commodities, much of which is exported to wealthy consumer nations, unsustainable bushmeat hunting, the illegal pet trade, the capture of primates for body parts, expanding road and rail networks, mining, dam building, oil and gas exploration, and the threat of emerging diseases. Over the next several decades, human population increase, agricultural expansion, and climate change are expected to contribute significantly to the loss of additional suitable habitat and a reduction in the viability of local primate populations. If we are to avoid this impending extinction crisis, primate researchers must prioritize projects designed to mitigate the effects of habitat change on ecosystems health and biodiversity, and play a greater role in conservation and environmental policy by educating global citizens and political leaders. In addition, the international community will need to work with governments in primate habitat countries to expand the number of protected areas that contain primate species (94 primate species have $<10 \%$ of their range in protected areas). In this special issue of the International Journal of Primatology, we bring together researchers from a wide range of disciplines to examine the current and future threats to primate population persistence, and present local, country, and regional solutions to protect primate species.
\end{abstract}

Keywords Sustainability $\cdot$ Habitat loss $\cdot$ Scientific activism $\cdot$ Species survivorship

Handling Editor: Joanna Setchell

Paul A. Garber

p-garber@illinois.edu

Extended author information available on the last page of the article 


\section{Introduction}

In 2009, a group of scientists defined the global commons as those elements of the biosphere (atmosphere, water, forests, and biodiversity) that sustain life on Earth and regulate the stability and resilience of our planet (Rockström et al., 2009; Steffen et al., 2015). Unfortunately, calls to protect the global commons have not been followed, and recent estimates indicate that the earth's biocapacity per capita has decreased steadily over the past several decades (Fig. 1), and some 1 million animal and plant species are threatened with extinction as a result of environmental degredation caused by human activities (IPBES, 2019). This includes many of the world's non-human primates, our closest living biological relatives. Primates represent the third most speciose mammalian radiation. They are distributed across 91 countries, mainly in the tropical forests of Mexico, Central and South America, Africa, Madagascar, and South and Southeast Asia, and represent an important component of the Earth's terrestrial biodiversity. Nonhuman primates provide essential models for understanding evolutionary and adaptive processes, as well as the biology, evolution, and behavior of humans. The natural activities of strepsirrhines, tarsiers, monkeys, and apes support a range of community-wide ecological functions and services (e.g., seed dispersal, pollination, predator-prey relationships) that promote forest regeneration and carbon sequestration, and provide benefits to local human populations (Estrada et al., 2017).

We begin by outlining the current state of the primate extinction crisis and the set of anthropogenic pressures that have contributed to primate population decline worldwide. We then introduce the goals of the special issue, which focus on examining the local and regional effects of climate change, infrastructure development, emerging diseases, and hunting on ecosystems health and primate persistence. The special issue also includes a discussion of innovative technologies that provide researchers with new and non-invasive ways of monitoring the demography, genetic structure, and health of wild primate populations, and two articles that advocate for primatologists playing a greater role in conservation education, public policy, and environmental activism. We end with a discussion of the responsibility of consumer

Fig. 1. Earth biocapacity per capita decline and human population growth over time. Clearly, humans are having a significant impact upon the Earth's capacity to support life. (Source of data Global FootPrint Network: http://data.footprintnetwork. org/).

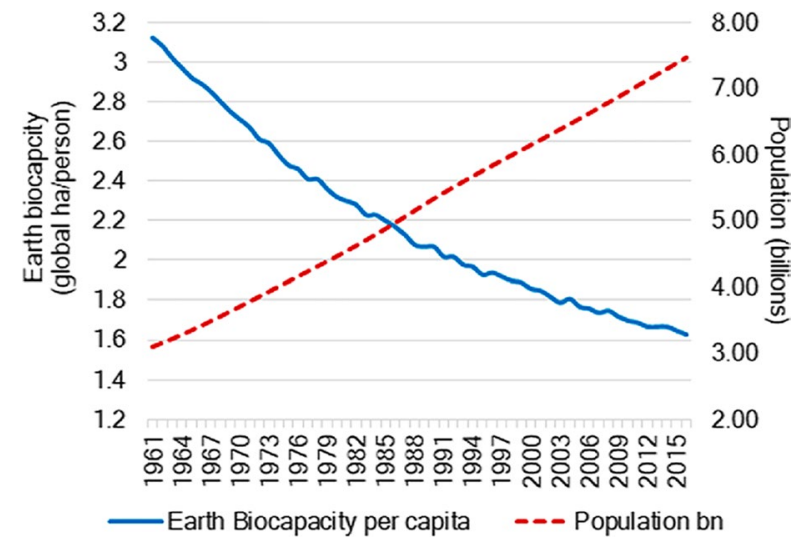


nations and corrupt local governments in driving the primate conservation crisis, and recommend policies that promote forest regeneration, limit the effects of climate change, and expand the system of protected areas available to primates.

\section{The Primate Extinction Crisis}

Field studies of wild nonhuman primates have grown exponentially over the past 40 years, and despite the fact that our knowledge of primate behavior, ecology, diet, and social and mating systems has expanded greatly, detailed and long-term information is available for only a handful of species (Bezanson \& McNamara, 2019; Estrada et al., 2017). A recent analysis found that during the 5-year period between 2011 and $2015,2 \%$ of primate species $(n=10)$ accounted for $36 \%$ of all primate field publications, and only $18 \%$ of those articles focused on the $30 \%$ of primate species listed by the IUCN as critically endangered (Bezanson \& McNamara, 2019). Given that we are facing a major conservation crisis, with more than $65 \%$ of extant primate species $(n=c a$ 521) threatened with extinction (up from $60 \%$ just 5 years ago, IUCN, 2021), and $\sim 93 \%$ characterized by declining populations, we must act now to rethink priorities for field research, develop new technologies, methodologies, and modeling approaches to survey, census, observe, and protect wild primate populations (Piel et al., 2021, this issue; Bicca-Marques et al., 2021, this issue), and engage more directly in scientific advocacy and scientific activism to mitigate the anticipated effects of climate change and habitat conversion on ecosystems health and biodiversity (Garber, 2021, this issue; Meyer \& Pie, 2021, this issue).

Over the past several decades, escalating anthropogenic pressures leading to extensive loss, fragmentation, and degradation of tropical forests (Estrada et al., 2017; IUCN, 2021) driven by expanding industrial agriculture (Estrada et al., 2019), logging, unsustainable bushmeat hunting, the illegal trade of primates as pets and as body parts, expanding road and rail networks into previously isolated areas (Ascensão et al., 2021, this issue), zoonotic disease transmission (Bicca-Marques et al., 2021, this issue), and the effects of climate change (Li et al., 2018; Carvalho et al., 2019; IUCN, 2021; Meyer \& Pie, 2021, this issue) have contributed to primate population decline. Recent ecological modeling predicts that by the end of the century, the four primate-richest countries in the world (Brazil, Madagascar, Indonesia, and the Democratic Republic of the Congo account for ca 290 species or $65 \%$ of all primate species) will lose 32-78\% of their existing habitat to agricultural expansion (Estrada et al., 2018). During this same time frame, 80-100\% of primate species in nine of the top 15 primate-richest countries are projected to become extinct or be threatened with extinction (Estrada et al., 2019).

Primate population decline is occurring against a backdrop of a growing worldwide demand for agricultural and nonagricultural commodities driven principally by an expanding human population (set to approach 10 billion by 2050) and a rapidly rising middle-class diet emphasizing greater meat consumption and increased use of natural resources (Estrada et al., 2019, 2020). Deforestation of primate habitats continues to increase steadily (Fig. 2), with ca 180 Mha of tropical forest (30\% canopy cover) lost between 2001 and 2018 (Estrada et al., 2020; GFW, 2019). This 

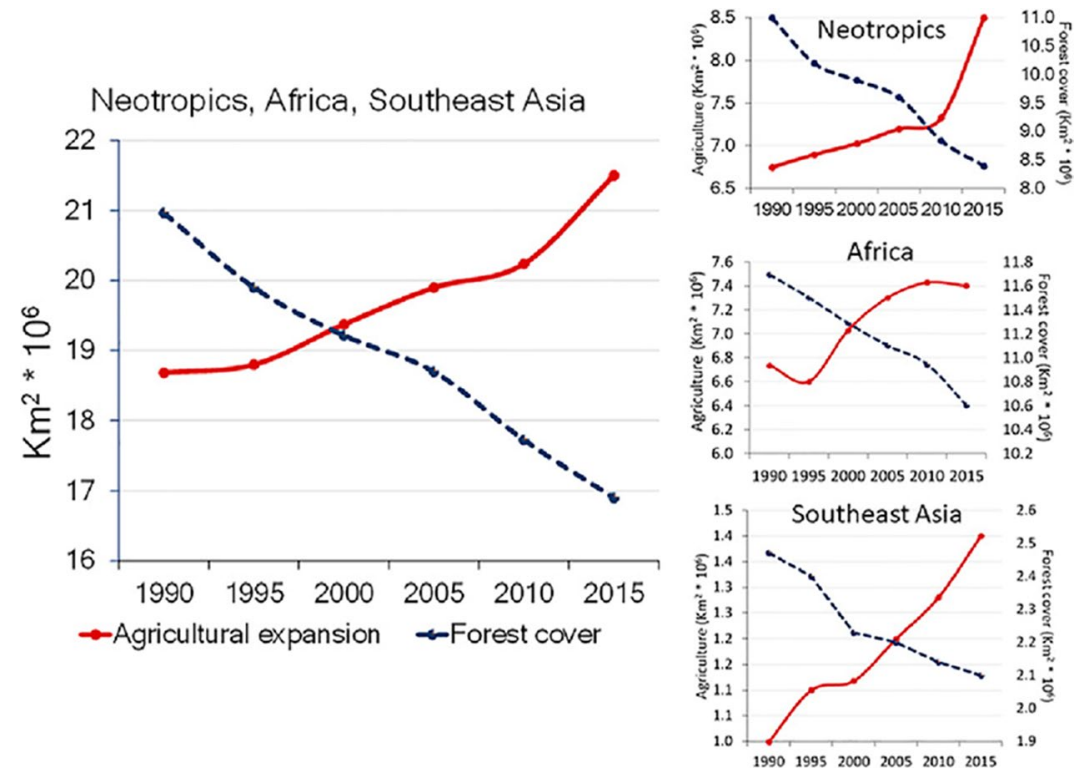

Fig. 2. A rapid decrease in forest cover and an accelerated agricultural expansion over time is evident in primate-range regions for the 20-year period shown on the graph. Mirror image trends are also evident for individual primate-range regions. (Source of raw data, FAOSTAT: faostat.fao.org/site/377/DesktopDefault.aspx? PageID=377\#ancor. Consulted August 2020).

represents an area roughly equivalent to the combined land mass of Spain, France, Germany, and the UK. The expanding local, regional, and global market demands for the production and trade of soy, palm oil, natural rubber, beef, forestry products, fossil fuels, and metals, minerals, and gemstones by tropical countries have increased from US\$382 bn in 2000 to US\$1.1 trillion in 2016. This increase in the value of traded commodities is paralleled by significant increases in the amount traded (7.1 bn tonnes in 2000 more than doubled to 14.9 bn tonnes in 2016) (Chatham House, 2019; Estrada et al., 2019), and has contributed significantly to degraded and toxic landscapes in primate range regions. For example between 2000 to 2010, 30\% of deforestation in Brazil, the primate-richest country in the world (116 species), was driven by global market demands for soybean and beef exports (Karstensen et al., 2013). Similarly, rubber production has increased by more than 2 million hectares in Southeast Asia over the past 2 decades (Ahrends et al., 2015; Estrada et al., 2019), and an additional 8 million hectares of rubber plantations will be required to meet world demands by 2024 (Warren-Thomas et al., 2015). Rubber expansion in Southeast Asia represents a direct threat to the ecology of several protected reserves that contain primates, most noticeably orangutans, langurs, and gibbons (Estrada et al., 2019; Li et al., 2018; Sloan et al., 2018).

The United Nations Food and Agriculture Organization (OECD-FAO, 2021) predicts that beef consumption worldwide will increase by $5.6 \%$ by the end of this decade, with the majority of this increase occurring in low-income countries. This coincides with a decades-long trend in the expansion of cattle stocks in primate 
range countries, from 528 million head in 1960 to 1.2 billion head in 2016. Expanding cattle production has resulted in in the conversion of $c a 500$ Mha to pastures and rangelands for beef production, leading to the extensive loss of primate habitats and increased levels of GHG emissions (see Fig. 5 in Estrada et al., 2019). Finally, global demand for oil and natural gas is expected to grow by $30-50 \%$ by 2035 , and primate-rich areas such as the Amazon basin, and tropical forests in Malaysia and Borneo will be greatly affected (Bebbington et al., 2018). Oil and gas concessions in the primate-rich western Brazilian Amazon and in forested areas of Colombia, Ecuador, Perú, and Bolivia, already cover $c a 1 \mathrm{Mkm}^{2}$. Many of these prospective energy fields spatially intersect protected areas and the territories and traditional lands of Indigenous Peoples, who have acted as stewards of these lands for thousands of years (Garnett et al., 2018). We are facing an impending primate extinction crisis, and if we are to protect the world's primates and their habitats, primate scientists must take a more activist role in educating the public and political leaders, and driving public policy (Garber, 2021, this issue).

\section{Goals of the Special Issue}

In this special issue, we bring together scholars from a variety of disciplines including primatology, anthropology, environmental sciences, ecology, zoology, conservation technology, global health, wildlife management, conservation biology, and climatology to examine the drivers of primate population decline, model the projected effects of these drivers on ecosystems health and primate persistence, and present local, country, and regional solutions that if implemented represent our best chance to protect threatened and nonthreatened primate species. Articles in the special issue also describe new technologies that provide more accurate and cost-effective ways of monitoring primate population demography, gene flow, and health, and discuss the role of scientific advocacy and scientific activism as essential tools to promote primate conservation.

The first article of the special issue by Fernández et al. (2021) provides a review and evaluation of the conservation status of primates inhabiting Mexico, Central, and South American, mainland Africa, Madagascar, and Asia; models the primary threats to primate population persistence in each region; and identifies the most prominent emerging drivers of primate population decline. Their results indicate that Madagascar (96.3\%) and Asia (83.7\%) have the largest proportion of threatened species, and that although industrial agriculture and biological resource use (i.e., hunting, live capture, and logging) are the most prevalent threats to primates worldwide, in Africa human intrusion and climate change negatively impacted $\sim 41 \%$ of species, whereas in the Americas, livestock farming and ranching negatively impacted $48 \%$ of species. In addition, climate change and infectious diseases appear to be significant emerging threats across all regions. These authors highlight the fact that unless urgent action is taken, we will not be able to avert a primate extinction crisis.

In article 2, Meyer and Pie (2021) use phylogenetic comparative methods to examine the anticipated effects of climate change on primate population persistence. 
They found that by the end of the century, changes in temperate and rainfall across much of the primate distribution will be so severe that effectively responding to these new conditions would require rates of adaptive evolutionary change that exceed rates previously recorded. Moreover, for many arboreal species, distributional shifts in response to changing habitats are unlikely to track the speed and rate of climate change. Finally, increased frequency and severity of droughts and cyclones are expected to impact some $20 \%$ of primate species. Thus, in the absence of a significant reduction in the burning of fossil fuels and the emission of green house gases, climate may become the primary driver of primate population decline over the last half of the 21 st century.

In their article on the affects of linear infrastructures on primate populations, Ascensão et al. (2021) examine the impact of roads, powerlines, and rail systems on habitat fragmentation in regions characterized as having a high conservation value for primates and in regions characterized by a low conservation value for primates. By the year 2050, 25 million $\mathrm{km}$ of additional roads and railways are expected to be constructed in tropical regions worldwide. This will increase accessibility to previously undisturbed areas for colonization, resource extraction, mining, temporary and permanent settlements, gas and oil exploration, and increased bush-meat hunting. Based on their analysis, all species of great apes and gibbons are threatened by expanding linear infrastructures, as are several cercopithecid, atelid, cebid, and lorisid taxa. In addition, these infrastructures serve as barriers to animal migration and gene flow. Ascensão et al. (2021) identify areas of high primate conservation value in Indonesia, Madagascar, the Amazon and Congo basins, the Atlantic Forest of Brazil, the Guinean forests of the Ivory Coast, Guinea, Nigeri, the Democratc Republic of Congo, Myanmar, India, and Vietnam for which the threat of additional transportation infrastructure construction is of immediate concern.

Emerging diseases represent a major threat to human and nonhuman primate populations. In their article on the risk of yellow fever to Asian primates, BiccaMarques et al. (2021) model the threat of infection risk based on forest cover, climate, and mosquito vectors. They found that regions of southern India, Indonesia, and Malaysia represent high-risk zones for the spread of yellow fever. This zone of high risk coincides with the ranges of 44 primate species including orangutans, gibbons, langurs, tarsiers, odd-nosed monkeys, macaques, and lorises. Given that yellow fever is not native to Asia, a region-wide human vaccination campaign would be an effective tool to pre-empt the spread of yellow fever to nonhuman primate populations.

Borgerson et al. (2021) examine the effects of household hunting on the conservation status of lemur populations (42 species) across a range of ecosystems in Madagascar. The highest levels of hunting were found to occur in the rainforests of northeastern Madagascar. The data also indicated that smaller-bodied species and local lemur availability were the primary factors affecting which species were targeted. Hunting pressure was highest near protected areas, and the two most common prey were the greater dwarf lemur (Cheirogaleus major) and the white-headed lemur (Eulemur albifrons). Some 2,000 to 200,000 lemurs were consumed per year in the vicinity of each of ten protected study areas. These authors recommend that given food insecurity and poverty in Madagascar, an effective measure to reduce lemur 
hunting is to provide local villagers with access to low-cost alternative sources of protein, such as insects and poultry.

In their article on the conservation status and risk of extinction faced by the Critically Endangered blonde titi monkey (Callicebus barbarabrownae), Barreto et al. (2021) use species distribution modeling and population viablility assessments to predict expected changes in the distribution and availability of suitable habitat. Blonde titis naturally inhabit an extremely hot and dry savanna (Caatinga) habitat that has been heavily disturbed by human activities, most noticeably hunting and deforestation. Climate change also is likely to alter this environment. Current estimates indicate a remaining total population of some 1,000 blonde titis (IUCN, 2021). The models predicted that over the next 50 years, one-third of the current species distribution will be lost, and that $85 \%$ of the current forest patches that contain populations of blonde titis will lose those populations. These authors argue that conservation management programs that connect small forest fragments to larger forest patches offer the most effective solution to protecting this species from extinction.

Piel et al. (2021) provide a review of state-of-the-art noninvasive technologies including portable field labs, drones, cameras, and acoustic devices that facilitate the collection and analysis of large datasets needed for primate conservation. Using these technologies, along with improvements in machine learning, researchers can collect continuous data covering larger spatial scales and over long periods of time. In addition, the availability of portable genomics labs enable researchers to obtain information on the sex, health, diet, genomics, and kinship of individual group members and solitary individuals, from non-invasive fecal samples while in the field. An added strength of this article is the authors' discussion of the ethics of remote data collection, as well as the advantages and limitations of using these technologies for addressing research questions.

In his article on scientific advocacy and scientific activism as essential tools in primate conservation, Garber (2021) argues that if we are to save primates from extinction, primate scientists and their professional societies will need to educate and mobilize global citizens, the media, business leaders, and politicians in consumer nations and primate habitat countries. This will require collective action in the form of peaceful demonstrations, boycotts of forest-risk commodities, and letter-writing to create transformational change. As researchers and educators, primate scientists possess the expertise and skills required to take the lead in public policy debates on environmental health and conservation. This is one of our most important professional responsibilities. This article is a call for action, and the time to act is now!

In the final paper of this special issue, Huneycutt and Taglialatela (2021) offer additional insights into the important role that primate scientists must play in driving public policy by engaging and educating both the public and lawmakers. These authors, however, go one step further and advocate that if we are to be successful in protecting primate populations worldwide, we need to expand our efforts by working with educators to develop and implement age-appropriate content and curricula on environmental protection for primary and secondary students. This can be accomplished by virtually sharing our field experiences with young students and 
presenting them with examples of how our efforts as scientists contribute to protecting threatened animal species and countering climate change.

\section{The Responsibility of Consumer Nations in Driving the Primate Conservation Crisis}

Although the Group of 20 (G-20), an intergovernmental forum composed of the weathiest nations, accounts for $\sim 60 \% \%$ of the world's population, demand from consumers living in G-20 countries accounts for over $75 \%$ of world trade. Member countries of the G-20 are the primary importers of forest-risk resources, emphasizing the disproportionate land-use footprint on primate range regions by a small number of high- and middle-income countries (Chatham House, 2019; Estrada et al., 2019). Many citizens in primate habitat countries are food insecure (nearly 2 billion people worldwide do not have daily access to safe food and water; FAO, IFAD, UNICEF, WFP, and WHO, 2020), and yet the bulk of agricultural and meat products produced in these countries are sold for export. During the period between 2000 to 2016, primate-range countries increased food exports two- to four-fold (Estrada et al., 2019).

These growing demands for agricultural and nonagricultural commodities from the tropics are increasingly being met by global supply chains associated with multinational corporations rather than local producers (EcoNexus, 2013). The majority of these corporations are centered in the global north and control the extraction and trade of food and non-food commodities from tropical primate-harboring regions. The top agribusiness conglomerates that produce and trade in, for example, soybeans, palm oil, and natural rubber are all leaders in the production and sale of fertilizers and pesticides, and therefore have an obvious financial interest in promoting the continued use of these products (Ascensão et al., 2018; Estrada et al., 2019). Agrochemicals contribute to the pollution of soil, above- and below-ground water, and have a significant negative impact on insect biodiversity that is essential for sustainable agriculture in primate-range countries. Because of extreme poverty in several primate-range regions, especially in several African nations, the mining of metals, minerals, and gemstones is accompanied by the exploitation of men, women, and children, as well as the displacement of Indigenous Peoples from their traditional lands. In some cases, unsustainable global market demands have fueled local civil conflicts, as is the case with blood diamonds and conflict minerals (e.g., tantalum) (Alvarez-Berrios \& Aide, 2015; Garcia et al., 2017). Civil conflicts, wars, and government corruption have resulted in political instability, refugee crises, hunger, famine, and environmental degradation in several primate habitat countries (Estrada et al., 2018).

Unfortunately, the conservation status of many primate species and ecosystems will deteriorate even further with the implementation of the Belt and Road Initiative (BRI) led by China. The initiative involves the expenditure of USD 1 trillion dollars to develop massive infrastructure projects such as roads, railways, dams, and megadams for the production and extraction of agricultural products and natural resources from primate-range nations (OECD, 2018). The BRI is expected to involve up to 
140 countries in Asia, Africa, and Latin America (Green Finance \& Development Center, 2021), and to result in extensive and permanent primate habitat loss and environmental degradation, placing regional biodiversity and many endangered primates at increased risk (Alamgir et al., 2017; Ascensão et al., 2018; Liu et al., 2019)

\section{Protected Areas, Human Population Increase, and Primate Conservation}

A first line of defense in limiting the ever-expanding production and extraction of forest-risk commodities is the current system of natural protected areas. While most primate-range countries have met the Aichi target (UNGEF, 2019) of establishing ca $17 \%$ of their land area as protected areas, populations of only a small fraction of primate species are found within the boundaries of these areas. For example, in Brazil, Madagascar, Indonesia, and the Democratic Republic of the Congo, countries which together harbor close to $65 \%(n=c a 324)$ of the world's primate species, only $14-38 \%$ of primate populations are found in protected areas (Estrada et al., 2018). Worldwide, 94 primate species have less than $10 \%$ of their remaining distribution in legally protected areas. Thus many populations and species lack adequate protection. Moreover, as a response to global market demands and a lack of sufficient funding for park rangers, illegal artisanal mining, along with bushmeat hunting and the capture of primates for the illegal pet trade, take place inside or on the boundaries of protected areas, further endangering primate populations (Estrada et al., 2019; Fernández et al., 2021, this issue). In Madagascar, the illegal mining of high value metals and gems in protected areas has negatively impacted several lemur species (Gould \& Sauther, 2016). In Brazil, between 2001 and 2013, about 1,600 gold mining sites were active within 13 protected area, resulting in poisoned streams, deforestation, and increased bush-meat hunting of primates (AlvarezBerrıos \& Aide, 2015).

Primate conservation cannot be properly discussed or evaluated without considering the well-being of human populations in primate-range regions. The world's human population is currently estimated to be $c a$ bn people, with $c a 60 \%$ found in primate range countries. By 2050, the human population in primate-habitat countries is expected to increase from 5 to $7 \mathrm{bn}$, accounting for some $70 \%$ of the addition human population growth (Estrada et al., 2020). Estimates are that food production will need to increase from the current 8 bn to almost 14 bn tonnes per year to feed this growing population (UNPD, 2019). This will certainly exert enormous pressure on primate habitats and environmental health, unless food production is done using sustainable-management practices and on land that already has been cleared or impacted (Rockström et al., 2017; Rust et al., 2020; UNGEF, 2019). Unfortunately, most primate-range countries are characterized by high levels of poverty and income inequality, low human development, low food security. high levels of corruption, and weak governance (Estrada et al., 2020), all factors contributing to primate population decline. As delineated by the UN Sustainable Development Goals, enhancing the welfare, well-being, and security of local human populations in primate-range countries is of paramount importance, if we are to move forward with 
effective policies to protect the world's primates and promote biodiversity conservation (UNDESA, 2020).

\section{Policies to Avoid Future Widespread Primate Extinction}

Under a business-as-usual scenario, models of agricultural expansion and primaterange contraction indicate that an additional $\mathrm{ca} 68 \%$ of the area currently occupied by primates will be converted to agricultural use by the year 2100 . This will result in unprecedented spatial conflict with $\mathrm{ca} 75 \%$ of primate species worldwide (Estrada et al., 2017). All modeling scenarios (SSP-5, RCP 8.5, and SAR) indicate significant increases worldwide in the number of primate species threatened with extinction (Estrada et al., 2017, 2019, 2020; also see Barreto et al., 2021, this volume; Ascensão et al., 2021, this volume). Considering that total global commodities production is expected to more than double, from $85 \mathrm{bn}$ tons today to $186 \mathrm{bn}$ by the year 2050 (Chatham House, 2019), reversing the current trend of primate population decline and extinction due to habitat loss and degradation will require immediate action and unwavering global resolve to reduce the world's per capita demand for forest-risk commodities from primate-range regions (Green et al., 2020). The looming task before us is to determine how to reduce the planet's addiction to commodities from the tropics, improve local food security and distribution, and implement policies that diminish the environmental footprint of high- and middle-income consumer nations.

Effective policies that promote primate conservation must begin by assigning responsibility for environmental damage to international corporations that control commodities' production, exports, and supply chains, and unsustainably produce and extract crops and natural resources from primate-range countries. Of paramount importance is the need to change food habits in G20 nations (e.g., use less oil seed, eat less meat, diminish the extraction of tropical timber, fossil fuels, metals, minerals, and gemstones from the tropics), move rapidly to green energy, and implement sustainable land-use practices (Estrada et al., 2019; Willett et al., 2019). Only then will we be able to improve the standard of living of local human communities, safeguard natural ecosystems, protect primates and other threatened taxa, and engage in a global reforestation effort to mitigate climate change (UNDP, 2019; Meyer \& Pie, 2021, this volume).

Given the role of livestock production in converting forested land to pasture and in producing greenhouse gases (14.5\% of GHG emissions worldwide are produced by livestock, principally cattle; FAO, 2020) decreasing the demand for a meat based diet remains one of the most effective measures for protecting natural ecosystems and biodiversity worldwide. An alternative to meat-eating is the increased consumption of protein-rich insects (Borgerson et al., 2021, this issue). Other solutions to the greening of agriculture and other extractive industries include a carbon tax designed to reduce consumption in high-income nations, using some of these funds to offset the costs of creating local markets and supply chains in primate habitat countries that increase domestic access to a nutritious and secure food supply and alleviate poverty, and offering incentives and subsidies to organizations and communities that 
promote sustainable and environmentally friendly agricultural production and nonfood resource extraction (Estrada et al., 2019).

Additional conservation measures that governments, international organizations, and global citizens must prioritize include: (A) promoting sustainable intensification of agriculture on already cleared lands by incorporating the use of sustainable farming techniques and minimizing the use of agrochemicals, (B) restoring degraded forests and soil while protecting natural landscapes that store carbon and protect biodiversity and water supplies, (C) requiring commodities-importing countries to support the conversion of unused agricultural and pasturelands to secondary forests as an important conservation measure, (D) expanding the system of natural protected areas and including buffer zones and migration corridors to enhance primate dispersal, gene flow, and ecological connectivity, and (E) encouraging global citizens to demand that political leaders and world institutions take action to minimize the negative ecological, economic, and social impacts of climate change.

\section{Conclusions}

Protecting the global commons from widespread destructive human activities is critical to mitigate climate change, to ensure the persistence of the world's terrestrial ecosystems, to stop the loss of biodiversity, and to protect nonhuman primates from the catastrophic consequences of climate change, habitat loss, and population decline caused by unsustainable human activities. These activities include the expansion of industrial agriculture, extensive cattle ranching, logging, oil and gas extraction, mining, dam building, and the expansion of road networks in primate-range regions. Other important pressures are heightened bushmeat hunting and the illegal trade of primates as pets and primate body parts as humans expand into previously protected or undisturbed areas and breakdown barriers that have limited human-nonhuman primate contact and the threat of emerging diseases (Bicca-Marques et al., 2021, this issue). This is critically important given the current COVID-19 pandemic, as there is evidence that several primate species are susceptible to the Sars-COV- 2 virus (Gillespie \& Leendertz, 2020; Melin et al., 2020; Shan et al., 2020). These pressures often act in synergy, exacerbating primate population decline, especially in primate-range regions that overlap extensively with a large, and rapidly growing human population characterized by a high degree of poverty (Estrada et al., 2017, 2020). We hope that the information presented in this special issue serves as a catalyst to safeguard the world's primates from extinction.

Acknowledgments We would like to thank Dr. J. Setchell, editor of IJP, for her commitment to this special issue and her comments on an earlier version of this manuscript. AE and PAG are grateful to all of the contributing authors to this special issue for their original insights with regard to primate conservation. PAG wishes to acknowledge Chrissie, Sara, Jenni, and Dax for their support, guidance, and encouragement in my efforts to save primates from extinction.

\section{Declarations}

Conflict of linterest The authors declare that they have no conflict of interest. 
Ethical Note This manuscript did not involve the use of wild or captive primates. No licenses were required to carry out the work.

\section{References}

Ahrends, A., Hollingsworth, P. M., Ziegler, A. D., Fox, J. M., Chen, H., Su, Y., \& Xu, J. (2015). Current trends of rubber plantation expansion may threaten biodiversity and livelihoods. Global Environmental Change, 34, 48-58. https://doi.org/10.1016/j.gloenvcha.2015.06.002.

Alamgir, M., Campbell, M. J., Sloan, S., Goosem, M., Clements, G. R., Mahmoud, M. I., et al (2017). Economic, socio-political andeEnvironmental risks of road development in the tropics. Current Biology, 27, R1130-R1140. https://doi.org/10.1016/j.cub.2017.08.067.

Alvarez-Berrios, N. L., \& Aide, T. M. (2015). Global demand for gold is another threat for tropical forests. Environmental Research Letters, 10(1), e014006. https://doi.org/10.1088/1748-9326/10/1/ 014006.

Ascensão, F., Fahrig, L., Clevenger, A. P., Corlett, R. T., Jaeger, J. A. G., Laurance, W. F., et al (2018). Environmental challenges for the belt and road initiative. Nat Sustain, 1, 206-209. https://doi.org/ 10.1038/s41893-018-0059-3.

Ascensão, F., D’Amico, M., \& Barrientos, R. (2021). No planet for apes? Assessing global priority areas and species affected bylinear infrastructures. International Journal of Primatology. https://doi.org/ 10.1007/s10764-021-00207-5.

Barreto, H. F., Jerusalinsky, L., Eduardo, A. A., Alonso, A. C., Santos Júnior, E. M., Beltrão-Mendes, R., Ferrari, S. F., \& Gouveia, S. F. (2021). Viability meets suitability: distribution of the extinction risk of an imperiled titi monkey (Callicebus barbarabrownae) under multiple threats. International Journal of Primatology. https://doi.org/10.1007/s10764-021-00259-7.

Bebbington, A. J., Bebbington, D. H., Sauls, L. A., Rogan, J., Agrawal, S., Gamboa, C., et al (2018). Resource extraction and infrastructure threaten forest cover and community rights. Proceedings of the National Academy of Sciences of the United States of America, 115(52), 13164-13173. https:// doi.org/10.1073/pnas.1812505115.

Bezanson, M., \& McNamara, A. (2019). The what and where of primate field research may be failing conservation. Evolutionary Anthropology, 28(4), 166-178. https://doi.org/10.1002/evan.21790.

Bicca-Marques, J. C., Rabelo, R. M., de Almeida, M. A. B., \& Sales, L. P. (2021). The risks of yellow fever to Asian primates. International Journal of Primatology. https://doi.org/10.1007/ s10764-021-00223-5.

Borgerson, C., Johnson, S. E., Hall, E., Brown, K. A., Narváez-Torres, P. R., Rasolofoniaina, B. J. R., Razafindrapaoly, B. N., Merson, S. D., Thompson, K. E. T., Holmes, S. M., Louis Jr., E. E., \& Golden, C. D. (2021). A national-level assessment of lemur hunting pressure in Madagascar. International Journal of Primatology, 36(1), 74-93. https://doi.org/10.1007/ s10764-021-00215-5.

Carvalho, J. S., Graham, B., Rebelo, H., Bocksberger, G., Meyer, C. F. J., Wich, S., \& Kühl, H. S. (2019). A global assessment of primates under climate and landuse /cover scenarios. Global Change Biology, 25(9), 3163-3178. https://doi.org/10.1111/gcb.14671.

Chatham House. (2019). The Royal Institute of International Affairs. https://resourcetrade.earth/.

EcoNexus. Berne Declaration \& EcoNexus. (2013). https://es.scribd.com/document/219183091/ Agropoly-Econexus-Berne-Declaration

Estrada, A., Garber, P. A., Rylands, A. B., Roos, C., Fernandez-Duque, E., Di Fiori, A., et al (2017). Impending extinction of the world's primates: why primates matter. Science Advances, 3, e1600946.

Estrada, A., Garber, P. A., Wich, S., Mittermeier, R. A., Gouveia, S., Dobrovolski, R., et al (2018). Primates in peril: the significance of Brazil, Madagascar, Indonesia and the Democratic Republic of the Congo for global primate conservation. PeerJ, 6, e4869. https://doi.org/10.7717/peerj.4869.

Estrada, A., Garber, P. A., \& Chaudhary, A. (2019). Expanding global commodities trade and consumption place the world's primates at risk of extinction. PeerJ, 7, e7068. https://doi.org/10.7717/peerj. 7068 . 
Estrada, A., Garber, P. A., \& Chaudhary, A. (2020). Current and future trends in socio-economic, demographic and governance factors affecting global primate conservation. PeerJ, 8, e9816. https://doi. org/10.7717/peerj.9816.

FAO. (2020). Key facts and findings. https://www.fao.org/news/story/en/item/197623/icode/.

FAO, IFAD, UNICEF, WFP and WHO (2020). The State of Food Security and Nutrition in the World 2020. Transforming food systems for affordable healthy diets. FAO.

Fernández, D., Kerhoas, D., Dempsey, A., Billany, J., McCabe, G., \& Argirova, E. (2021). The current status of the world's primates: mapping threats to understand priorities for primate conservation. International Journal of Primatology, 39, 443-465. https://doi.org/10.1007/s10764-021-00242-2.

Garber, P. A. (2021). Advocacy and activism as essential tools in primate conservation. International Journal of Primatology. https://doi.org/10.1007/s10764-021-00201-x.

Garcia, L. C., Ribeiro, D. B., Oliveira-Roque, F., Ochoa-Quintero, J. M., \& Laurance, W. F. (2017). Brazil's worst mining disaster: corporations must be compelled to pay the actual environmental costs. Ecological Applications, 27(1), 5-9. https://doi.org/10.1002/eap.1461.

Garnett, S. T., Burgess, N. D., Fa, J. E., Fernández-Llamazares, A., Molnár, Z., Robinson, C. J., Watson, J. E. M., Zander, K. K., Austin, B., Brondizio, E. S., Collier, N. F., Duncan, T., Ellis, E., Geyle, H., Jackson, M. V., Jonas, H., Malmer, P., McGowan, B., Sivongxay, A., \& Leiper, I. (2018). A spatial overview of the global importance of Indigenous lands for conservation. Nature Sustainability, 1, 369-374.

Gillespie, T. R., \& Leendertz, F. H. (2020). COVID-19: Protect great apes during human pandemics. Nature, 579(7800), 497. https://doi.org/10.1038/d41586-020-00859-y.

Global Forest Watch (GFW). (2019). Global Forest Watch. https://www.globalforestwatch.org/

Gould, L., \& Sauther, M. L. (2016). Going, going, gone: Is the iconic ring-tailed lemur (Lemur catta) headed for imminent extirpation? Primate Conservation, 30, 89-101.

Green Finance \& Development Center. (2021). Countries of the Belt and Road Initiative. https://greenfdc. org/countries-of-the-belt-and-road-initiative-bri/

Green, A., Nemecek, T., Chaudhary, A., \& Mathys, A. (2020). Assessing nutritional, health, and environmental sustainability dimensions of agri-food production systems. Global Food Security, 26, 100406. https://doi.org/10.1016/j.gfs.2020.100406.

Huneycutt, S. P., \& Taglialatela, J. P. (2021). A response to "Advocacy and Activism as Essential Tools in Primate Conservation". International Journal of Primatology. https://doi.org/10.1007/ s10764-021-00237-z.

IPBES. (2019). Intergovernmental science-policy platform on biodiversity and ecosystem services. Available at https://www.ipbes.net/news/ipbes-global-assessment-summary-policymakers-pdf.

IUCN. (2021). The IUCN Red List of Threatened Species. Version 2019-2: http://www.iucnredlist.org

Karstensen, J., Peters, G. P., \& Andrew, R. M. (2013). Attribution of CO emissions from Brazilian deforestation to consumers between 1990 and 2010. Environmental Research Letters, 8(2), 024005. https://doi.org/10.1088/1748-9326/8/2/024005.

Li, B.-G., Li, M., Li, J., Fan, P., Qingyong, N., Lu, J., et al (2018). The primate extinction crisis in China: immediate challenges and a way forward. Biodiversity and Conservation, 27, 3301-3327. https:// doi.org/10.1007/s10531-018-1614-y.

Liu, X., Blackburn, T. M., Song, T., Li, X., Huang, C., \& Li, Y. (2019). Risks of biological invasion on the belt and road. Current Biology, 29(3), 499-505.e4. https://doi.org/10.1016/j.cub.2018.12.036.

Melin A. D., Janiak, M. C., Marrone, F., Arora, P. S., \& Higham, J. P. (2020). Comparative ACE2 variation and primate COVID-19 risk. Communications Biology, 3(1), 1-9.

Meyer, A. L. S., \& Pie, M. R. (2021). Climate change estimates surpass rates of climatic niche evolution in primates. International Journal of Primatology. https://doi.org/10.1007/s10764-021-00253-z.

OECD (2018). OECD Business and Finance Outlook (pp. 1-44). OECD Publishing.

OECD/FAO (2021). Agricultural Outlook 2021-2030. OECD Publishing. https://doi.org/10.1787/19428 846-en.

Piel, A. K., Crunchant, A., Knot, I. E., Chalmers, C., Fergus, P., Mulero-Pázmány, M., \& Wich, S. A. (2021). Noninvasive technologies for primate conservation in the 21st century. International Journal of Primatology. https://doi.org/10.1007/s10764-021-00245-z.

Rockström, J., Steffen, W., Noone, K., Persson, Å., Stuart Chapin III, F., et al (2009). A safe operating space for humanity. Nature, 461, 472-475. https://doi.org/10.1038/461472a.

Rockström, J., Williams, J., Daily, G., Noble, A., Matthews, N., Gordon, L., et al (2017). Sustainable intensification of agriculture for human prosperity and global sustainability. Ambio, 46(1), 4-17. https://doi.org/10.1007/s13280-016-0793-6. 
Rust, N. A., Ridding, L., Ward, C., Clark, B., Kehoe, L., Dora, M., et al (2020). How to transition to reduced-meat diets that benefit people and the planet. Science of the Total Environment, 718, 137208. https://doi.org/10.1016/j.scitotenv.2020.137208.

Shan, C., Yao, Y.F., Yang, X.L., Shi, Z.L., Zhou, Y.W., Wu, J., et al. (2020). Infection with novel coronavirus (SARS-CoV-2) causes pneumonia in Rhesus macaques. Cell Research (early view). https:// doi.org/10.1038/s41422-020-0364-Z

Sloan, J., Supriatna, J., Campbell, M. J., Alagmir, M., \& Laurance, W. F. (2018). Newly discovered orangutan species requires urgent habitat protection. Current Biology, 28(11), 650-651. https://doi.org/ 10.1016/j.cub.2018.04.082.

Steffen, W., Richardson, K., Rockström, J., Cornell, S. E., Fetzer, I., et al (2015). Planetary boundaries: guiding human development on a changing planet. Science, 347(6223). https://doi.org/10.1126/scien ce. 1259855.

UNDP (2019). Human development report 2019: Beyond income, beyond averages, beyond today-inequalities in human development in the 21st century. UN Development Program.

UNGEF (2019). UN Global Environment Facility (GEF). https://www.thegef.org/search/site/aichi.

United Nations Department of Economic and Social Affairs (UNDESA) (2020). United Nations Sustainable Development Knowledge Platform. https://sustainabledevelopment.un.org/.

United Nations Population Division (UNPD). (2019). World Population Prospects 2019. https://popul ation.un.org/wpp/Publications/Files/WPP2019_Highlights.pdf

Warren-Thomas, E., Dolman, P. M., \& Edwards, D. P. (2015). Increasing demand for natural rubber necessitates a robust sustainability initiative to mitigate impacts on tropical biodiversity. Conservation Letters, 8(4), 230-241. https://doi.org/10.1111/conl.12170.

Willett, W., Rockström, J., Loken, B., Springmann, M., Lang, T., Vermeulen, S., et al (2019). Our food in the Anthropocene: The EAT-Lancet commission on healthy diets from sustainable food systems. The Lancet, 393(10170), 447-492. https://doi.org/10.1016/S0140-6736(18)31788-4.

\section{Authors and Affiliations}

\section{Alejandro Estrada ${ }^{1,2}$ (D) Paul A. Garber ${ }^{2,3}$}

Alejandro Estrada

aestradaprimates@gmail.com

1 Institute of Biology, National Autonomous University of Mexico, Mexico, Mexico

2 International Centre of Biodiversity and Primate Conservation, Dali University, Dali, Yunnan, China

3 Department of Anthropology and Program in Ecology, Evolution, and Conservation Biology, University of Illinois, Urbana, IL, USA 